\title{
Spatial variability in nutritional status of arabic coffee based on dris index
}

\author{
Samuel de Assis Silva ${ }^{1 *}$, Julião Soares de Souza Lima², Daniel Marçal de Queiroz ${ }^{3}$
}

\begin{abstract}
The combined use of precision agriculture and the Diagnosis and Recommendation Integrated System (DRIS) allows the spatial monitoring of coffee nutrient balance to provide more balanced and cost-effective fertilizer recommendations.

The objective of this work was to evaluate the spatial variability in the nutritional status of two coffee varieties using the Mean Nutritional Balance Index (NBIm) and its relationship with their respective yields. The experiment was conducted in eastern Minas Gerais in two areas, one planted with variety Catucaí and another with variety Catuaí. The NBIm of the two varieties and their yields were analyzed through geostatistics and, based on the models and parameters of the variograms, were interpolated to obtain their spatial distribution in the studied areas. Variety Catucai, with grater spatial variability, was more nutritional unbalanced than variety Catuai, and consequently produced lower yields. Excess of Fe and Mn makes these elements limiting yield factors.
\end{abstract}

Key words: Yield, precision agriculture, geostatistics, leaf analysis.

\section{RESUMO}

\section{Variabilidade espacial do estado nutricional de variedades de café arábica com base no índice DRIS}

A utilização conjunta da agricultura de precisão e do Sistema Integrado de Diagnose e Recomendação (DRIS) permite o monitoramento espacial do balanço nutricional dos cafezais, proporcionando recomendações de adubações mais equilibradas e economicamente mais ajustadas. Por essa razão, este trabalho foi desenvolvido com o objetivo de avaliar a variabilidade espacial do estado nutricional de duas variedades de café arábica, por meio do índice de balanço nutricional, fornecido pelo DRIS, e sua relação com as respectivas produtividades. O experimento foi desenvolvido no leste de Minas Gerais, em duas áreas, sendo, uma, cultivada com a variedade Catucaí e, outra, com Catuaí. O IBNm das duas variedades, bem como suas produtividades, foram analisados por meio da geoestatística e, com base nos modelos e parâmetros dos variogramas, foram interpolados para obter sua distribuição espacial. A variedade Catucaí, com maior variabilidade espacial, encontra-se em maior desequilíbrio nutricional que a variedade Catuaí, e, consequentemente, com menor produtividade, sendo que os nutrientes Fe e Mn, por causa do seu excesso, são os mais limitantes.

Palavras-chave: Produtividade, agricultura de precisão, geoestatística, análise foliar.

Received for publication in february 2010 and approved in february 2011

* Corresponding author

${ }^{1}$ Agronomist Engineer, Doctor Science. Agricultural Engineering Department, Federal University of Viçosa, Av. Peter Henry Rolfs, s/n, 36571-000, Viçosa, MG, Brazil. e-mail: samuel-assis@hotmail.com

2 Agricultural Engineer, Doctor Science. Rural Engineering Department, Federal University of Espírito Santo, Alto Universitário, s/n, 29500-000, Alegre, ES, Brazil. e-mail: limajss@yahoo.com.br

${ }^{3}$ Agricultural Engineer, Ph.D. Agricultural Engineering Department, Federal University of Viçosa, Av. Peter Henry Rolfs, s/n, 36571-000, Viçosa, MG, Brazil. e-mail: queiroz@ ufv.br 


\section{INTRODUCTION}

The high nutrient export from the coffee crop and high fertilizer prices have made monitoring of nutritional status by leaf analysis an essential practice to provide more balanced and cost-effective fertilizer recommendations (Bataglia et al., 2004).

To achieve high yields, adequate fertilizer recommendations should be based mainly on limiting nutrients. Reis Jr et al. (2002) argue that identification of limiting nutrients, usually by soil fertility tests, has been increasingly supported by plant nutritional diagnosis through the Diagnosis and Recommendation Integrated System (DRIS).

DRIS is a method that assesses more accurately nutritional interactions, establishing the order of limiting nutrients, either by deficiency or excess, as well as a relative order of nutrient requirement of the crop (Silva et al., 2003). The system calculates an index for each nutrient, on the basis of inter-relationships among nutrients and compares them with a high-yield reference population. DRIS indices have the advantage of ranking nutrients in order of importance, from the most deficient up to the excessive (Bataglia et al., 2004). The system provides a means of identifying nutritional imbalances in order to increase crop yields through a more efficient use of nutrient inputs indicated by the diagnosis (Reis Jr \& Monnerat, 2003).

Variable rate application of fertilizers is closely related to the concepts of precision agriculture, which advocates the differential treatment of selected areas of a production field, based on intra-field crop variability and involves a whole process of investigation and diagnosis (Molin \& Menegatti, 2005).

Thus, fertilizer applications, based on specific plant deficiencies recommended by DRIS, can be optimized by using precision agriculture concepts, information on the spatial distribution of nutrients in the field and improved management practices, resulting in significantly increased profitability for coffee growers.

This study was carried out to evaluate the spatial variability of the nutritional status of two varieties of Arabic coffee, using the Mean Nutritional Balance Index (NBIm) provided by DRIS and its relationship with their respective yields.

\section{MATERIALAND METHODS}

The study was conducted in the "Zona da Mata" Region, Minas Gerais, in the municipality of Reduto, located between $20^{\circ} 45^{\prime}$ '45.4' S latitude and $41^{\circ} 32^{\prime}$ ' 9.75' W longitude, in two adjacent fields in the same hillside. The fields have been cultivated for five years with Coffea arabica L. variety Catucaí in the lower area of the slope
(Field 1) and variety Catuaí in the upper area (Field 2), both at a spacing of $2.0 \times 0.6 \mathrm{~m}$.

Soil of both fields are classified as Oxisols with thick humic A horizons (EMBRAPA, 1999).

We built up a regular grid, totaling 100 sampling points that were georeferenced using a total station, with 50 points in each area. Each sample point consisted of three plants.

Evaluations were carried out during the agricultural year 2007/2008. Leaves from each sampling point were collected in early December 2007 for nutritional status assessment. Leaves from the third and fourth pair of productive branches, in each of the four cardinal directions on each of the three plants at each point, were collected to determine contents of macro (N, P, K, Ca, Mg,S) and micronutrients ( $\mathrm{Fe}, \mathrm{Mn}, \mathrm{Cu}, \mathrm{Zn}$ and $\mathrm{B})$, according to methodology described by EMBRAPA (1997).

Production was evaluated in July 2008. Coffee cherries were harvested from the three plants and weighted. Then, a sample of $1.0 \mathrm{~kg}$ cherries were separated and dried in an oven at $70{ }^{\circ} \mathrm{C}$ to about $12 \%$ moisture. The dried coffee was processed and yield was converted to tonnes of processed coffee per hectare, according to Tomaz et al. (2005).

The DRIS reference population (norm) was taken from the work of Martinez et al. (2004), who established DRIS norms for different regions of Minas Gerais, including the "Zona da Mata" Region (more precisely, the Manhuaçu region).

Calculation of DRIS indices was based on the general formula proposed by Beaufils (1973), according to Silva et al. (2003), Bataglia et al. (2004) and Barbosa et al. (2006), where for a nutrient $\mathrm{Y}$ :

$$
I Y=\frac{\sum_{i=1}^{n} f\left(Y / X_{i}\right)-\sum_{i=1}^{n} f\left(X_{j} / Y\right)}{n+m}
$$

Values of intermediate functions $f(\mathrm{Y} / \mathrm{X})$ were calculated using the formula defined by Jones (1981), and values of the ratio of the two elements were calculated by the formula:

$$
f(Y / X)=[(Y / X)-(y / x)] * K / S
$$

where $f(\mathrm{Y} / \mathrm{X})$ is the function of the ratio of the two nutrients $\mathrm{Y}$ and $\mathrm{X}$ of the sample to be diagnosed; $\mathrm{Y} / \mathrm{X}$ is the value of the ratio of the two nutrients in the leaves under diagnosis, $y / x$ is the value of the norm (crop of reference), $\mathrm{K}$ is an arbitrary constant (10) and $\mathrm{S}$ the standard deviation of the ratio in the reference population

The average nutrient balance index (NBIm) for each sample is the average of the absolute values of DRIS indices of each nutrient divided by the number of nutrients involved: 


$$
\mathrm{NBI} m=\frac{\sum_{i=1}^{n} I Y_{n}}{n}
$$

The values found for DRIS indices, NBIm and yields of both varieties were analyzed by descriptive statistics. To check the candidates for outliers, we analyzed the upper and lower quartiles and data normality was tested by the Shapiro-Wilk's test, at 5\% probability level, using the software Statistica 6.0.

The average DRIS indices for nutrients were evaluated according to Wadt (1996) (Table 1).

NBIm data and yields were analyzed by geostatistics in order to verify the occurrence of spatial dependence, and, if so, to quantify its degree using the fitting of theoretical functions to experimental variogram models, based on the assumption of intrinsic stationarity, by the equation 4:

$$
\gamma^{*}(h)=\frac{1}{2 N(h)} \sum_{i=1}^{N(h)}\left[z\left(x_{i}\right)-z\left(x_{i}+h\right)\right]^{2}
$$

where $N(h)$ is the number of pairs of experimental observations $\mathrm{Z}$ (xi), $\mathrm{Z}(\mathrm{xi}+\mathrm{h}$ ), separated by a vector $\mathrm{h}$. For the fitting of theoretical models to experimental variograms, nugget effects $\left(\mathrm{C}_{0}\right)$, sill $\left(\mathrm{C}_{0}+\mathrm{C}_{1}\right)$, structural variance $\left(\mathrm{C}_{1}\right)$ and range $\left(\mathrm{A}_{0}\right)$ were determined with the $\mathrm{GS}^{+}$software. To select the models, we used the criterion of least squares, selecting the models with the highest $\mathrm{R}^{2}$ (coefficient of determination), lowest SQR (sum of squared residuals) and highest correlation coefficient obtained by the method of cross validation (Guimarães, 2000).

The spatial dependence index (SDI) was analyzed by the ratio $\mathrm{C}_{1} /\left(\mathrm{C}_{0}+\mathrm{C}_{1}\right)$ and the intervals proposed by Zimback (2001), which considers the spatial dependence as weak (SDI $<25 \%)$, moderate $(25 \% \leq \mathrm{SDI}<75 \%)$ and severe $(\geq 75 \% \mathrm{SDI})$.
With the spatial dependence confirmed, values of macronutrients and yields of the two coffee varieties were estimated for non-sampled areas and maps of spatial distribution were prepared using ordinary kriging. This geostatistical interpolation uses a linear unbiased estimator with minimum variance and takes into account the spatial variability structure found for the attribute.

\section{RESULTS AND DISCUSSION}

Table 2 shows the values of dispersion and central tendency of DRIS indices for leaf nutrients, the NBIm and yield of both varieties, after removal of outliers.

The mean and median are very close for the indices of all nutrients, indicating that data are normally distributed and confirmed by the Shapiro-Wilk's test. The exceptions were $\mathrm{Mg}, \mathrm{S}$ and $\mathrm{Cu}$ in variety Catuaí, which did not fit the normal distribution.

According to Wadt (1996) classification, N, P, Ca, Mg, $\mathrm{S}, \mathrm{Zn}$ and $\mathrm{Cu}$ are in equilibrium in both varieties, while the other nutrients are in excess, limiting crop yield. Excessive $\mathrm{Fe}$ and $\mathrm{Mn}$ were detected in both varieties, with IY values much higher than their respective NBIm, especially Fe in variety Catucaí $(40,53)$. These excesses may be associated with acid soils, either because of their own origin or the continued use of high doses of acidifying nitrogen fertilizers, which would lead to a high availability of Mn and $\mathrm{Fe}$, as these elements are more soluble in acidic $\mathrm{pH}$ (Malavolta, 1986; Marschner, 1995). Carvalho et al. (2005), in a nutritional diagnosis of coffee plantations in Manhuaçu - MG, also found that Fe and Mn occurred more frequently with more positive indices. Similar results were reported by Barbosa et al. (2006), studying Arabic coffee in northwestern Rio de Janeiro, where Fe and Mn were the nutrients that occurred with more positive indices, i.e., in excess.

Boron also occurs in excess in both varieties: 12.2 for variety Catucaí and 9.62 for Catuaí. According to Andrade

Table 1 - Criteria for classifying nutrient indices according to DRIS indices.

\begin{tabular}{lc}
\hline Nutritional Status & Criterion \\
\hline Deficient and limiting & 1. IY <0 \\
\hline Probably deficient & $\begin{array}{c}\text { 2. }|\mathrm{IY}|>\mathrm{NBIm} \\
\text { 3. IY is the índex of lowest value }\end{array}$ \\
\hline Balanced & 1. IY < \\
\hline Probably in excess & $2 .|\mathrm{IY}|>\mathrm{NBIm}$ \\
\hline & $1 .|\mathrm{IY}| \geq \mathrm{NBIm}$ \\
\hline In excess & $1 . \mathrm{IY}>0$ \\
& $2 .|\mathrm{IY}|>\mathrm{NBIm}$ \\
\hline
\end{tabular}

IY = DRIS índex of the nutrient and NBIm = average nutrient balance índex. Wadt (1996).

Rev. Ceres, Viçosa, v. 58, n.2, p. 256-261, mar/abr, 2011 
and Ferreira (2004), the main nutritional imbalances in coffee plantations are caused, among other nutrients, for excessive levels of $\mathrm{B}$.

The NBIm showed significant difference between the crops. Considering that, the lower the NBIm value, the more nutritionally balanced is the crop, variety Catucaí is significantly more unbalanced than Catuaí, which explains the higher yields of this variety.

The NBIm and yield of the two varieties showed spatial dependence (Table 3), indicating that the nutritional balance of the plants varies with the distance between samples, influencing the spatial response of yields. Because variograms showed well-defined sills, it was assumed, in this case, intrinsic stationarity, since there was no tendency for variation of nutrients and yield with the directions.

Both NBIm and yield of variety Catuaí showed greater spatial continuity, demonstrated by the range of spatial dependence, with $73 \mathrm{~m}$ for NBIm and $36 \mathrm{~m}$ for yield, which were, respectively, four and two times higher than the values found for Catucaí. Thus, it is easier to overcome nutritional imbalances for variety Catuaí, as there are more specific management zones, since NBIm and yield, measured within distances of $73 \mathrm{~m}$ and $36 \mathrm{~m}$ respectively, are correlated.

Table 2 - Descriptive statistics of DRIS indices, NBIm and yield of coffee varieties Catucaí ${ }^{1}$ and Catuaí2.

\begin{tabular}{|c|c|c|c|c|c|c|c|c|c|}
\hline \multirow{2}{*}{ Attributes } & \multicolumn{9}{|c|}{ Statistics } \\
\hline & Mean & Mediana & Minimum & Maximum & CV\% & $\mathbf{s}$ & Cs & $\mathbf{C k}$ & $\mathbf{w}$ \\
\hline $\mathrm{N}^{1}$ & -0.04 & -0.05 & -0.79 & 0.43 & 69.47 & -0.03 & -0.27 & -0.27 & $\mathrm{~ns}$ \\
\hline $\mathrm{N}^{2}$ & -0.09 & -0.08 & -0.62 & 0.44 & 24.38 & -0.02 & -0.33 & 0.42 & $\mathrm{~ns}$ \\
\hline $\mathrm{P}^{1}$ & -0.26 & -0.25 & -0.39 & -0.18 & 17.09 & -0.04 & -0.69 & 1.11 & $\mathrm{~ns}$ \\
\hline $\mathrm{P}^{2}$ & -0.29 & -0.27 & -0.47 & -0.13 & 28.05 & -0.08 & -0.40 & -0.53 & $\mathrm{~ns}$ \\
\hline $\mathrm{K}^{1}$ & -0.43 & -0.43 & -0.89 & 0.02 & 42.02 & -0.18 & 0.00 & 0.22 & $\mathrm{~ns}$ \\
\hline $\mathrm{K}^{2}$ & -0.50 & -0.49 & -0.77 & -0.23 & 24.00 & -0.12 & -0.49 & 0.18 & $\mathrm{~ns}$ \\
\hline $\mathrm{Ca}^{1}$ & -0.52 & -0.51 & -0.93 & -0.13 & 35.52 & -0.18 & -0.17 & -0.41 & $\mathrm{~ns}$ \\
\hline $\mathrm{Ca}^{2}$ & -0.44 & -0.42 & -0.65 & -0.26 & 22.95 & -0.10 & -0.43 & -0.46 & $\mathrm{~ns}$ \\
\hline $\mathrm{Mg}^{1}$ & -0.71 & -0.68 & -0.96 & -0.50 & 17.10 & -0.12 & -0.37 & -0.55 & $\mathrm{~ns}$ \\
\hline $\mathrm{Mg}^{2}$ & -0.57 & -0.55 & -0.82 & -0.32 & 19.97 & -0.11 & -0.58 & 0.31 & $*$ \\
\hline $\mathrm{S}^{1}$ & -0.53 & -0.52 & -0.75 & -0.36 & 19.67 & -0.10 & -0.45 & -0.58 & $\mathrm{~ns}$ \\
\hline$S^{2}$ & -0.41 & -0.39 & -0.66 & -0.22 & 24.51 & -0.10 & -0.68 & -0.03 & * \\
\hline $\mathrm{Fe}^{1}$ & 40.53 & 39.24 & 20.93 & 70.22 & 28.43 & 11.52 & 0.55 & -0.01 & $\mathrm{~ns}$ \\
\hline $\mathrm{Fe}^{2}$ & 22.25 & 21.49 & 11.51 & 39.37 & 27.40 & 6.10 & 0.68 & 0.15 & $\mathrm{~ns}$ \\
\hline $\mathrm{Mn}^{1}$ & 14.66 & 14.30 & 8.51 & 25.30 & 24.40 & 3.58 & 0.66 & 0.72 & $\mathrm{~ns}$ \\
\hline $\mathrm{Mn}^{2}$ & 14.61 & 13.81 & 5.56 & 26.64 & 37.24 & 5.44 & 0.42 & -0.71 & $\mathrm{~ns}$ \\
\hline $\mathrm{Cu}^{1}$ & 1.98 & 1.88 & 1.06 & 2.92 & 23.91 & 0.47 & 0.19 & -0.76 & $\mathrm{~ns}$ \\
\hline $\mathrm{Cu}^{2}$ & 2.92 & 2.64 & 0.57 & 6.64 & 55.13 & 1.61 & 0.53 & -0.74 & * \\
\hline $\mathrm{Zn}^{1}$ & 0.47 & 0.43 & 0.08 & 0.88 & 38.45 & 0.18 & 0.41 & -0.14 & $\mathrm{~ns}$ \\
\hline $\mathrm{Zn}^{2}$ & 0.35 & 0.36 & 0.01 & 0.66 & 44.44 & 0.16 & -0.18 & -0.43 & $\mathrm{~ns}$ \\
\hline $\mathrm{B}^{1}$ & 12.20 & 12.80 & 6.66 & 17.49 & 19.42 & 2.37 & -0.24 & -0.11 & $\mathrm{~ns}$ \\
\hline $\mathrm{B}^{2}$ & 9.62 & 9.68 & 6.74 & 12.49 & 16.39 & 1.58 & 0.04 & -0.85 & $\mathrm{~ns}$ \\
\hline $\mathrm{NBIm}^{1}$ & $6.75 \mathrm{a}$ & 6.84 & 4.12 & 10.33 & 21.75 & 1.47 & 0.32 & -0.25 & $\mathrm{~ns}$ \\
\hline $\mathrm{NBIm}^{2}$ & $4.83 \mathrm{~b}$ & 4.89 & 2.27 & 7.05 & 20.39 & 0.98 & 0.21 & 0.40 & $\mathrm{~ns}$ \\
\hline PROD $^{1}$ & $5.39 \mathrm{~b}$ & 5.13 & 1.83 & 8.66 & 30.19 & 1.63 & 0.28 & -0.65 & $\mathrm{~ns}$ \\
\hline $\mathrm{PROD}^{2}$ & $6.60 \mathrm{a}$ & 6.95 & 2.06 & 10.46 & 29.87 & 1.97 & -0.25 & 0.01 & $\mathrm{~ns}$ \\
\hline
\end{tabular}

PROD in t ha ${ }^{-1}$; CV\% - coefficient of variation; s - standard deviation; Cs - coefficient of symmetry; Ck - coefficient of kurtosis; * non normal distribution by Shapiro Wilk's test at $5 \%$ probability level; ${ }^{\text {ns }}$ - normal distribution by Shapiro Wilk's test at $5 \%$ probability level.

Table 3 - Models and Parameters of the mean variograms assigned for NBIm and yields of coffee varieties Catucaí and Catuaí.

\begin{tabular}{lcccc}
\hline \multirow{2}{*}{ Parameters } & Catucaí & Catuaí & & NBIm \\
\cline { 2 - 5 } Model & NBIm & Yield & Yield \\
\cline { 2 - 5 } & Exponential & Spherical & Gaussian & Spherical \\
\hline $\mathrm{C}_{0}$ & 0,75 & 0,33 & 0,80 & 0,40 \\
$\mathrm{C}_{0}+\mathrm{C}$ & 2,80 & 0,96 & 1,65 & 1,14 \\
$\mathrm{~A}_{0}$ & 25 & 18 & 73 & 36 \\
$\mathrm{R}^{2}$ & 79 & 63 & 87 & 90 \\
SDI & 73 & 64 & 52 & 65 \\
\hline
\end{tabular}

SDI - spatial dependence index 
Figure 1 shows maps (standardized scales to facilitate comparisons), where is evident the greater spatial continuity of variety Catuaí and its higher nutritional balance in almost the entire field. Most Catuaí plants have NBIm between 4 and 6 and none with values greater than 8 , while for Catucaí, despite the lower continuity, most plants have NBIm between 6 and 8 and a considerable area with plants having NBIm greater than 8 .
Figure 1 also shows that variety Catucaí, with greater nutritional imbalance mainly due to excessive $\mathrm{Fe}$ and $\mathrm{Mn}$ in leaf tissue, had lower yields, with a large proportion of the field with production of 4-6 $\mathrm{tha}^{-1}$.

Variety Catuaí had higher yields, as discussed above, and these higher values correspond to areas where NBIm values are lower because of the higher nutritional balance of the plants, since there is an inverse relationship between yield and NBIm (Figure 2).
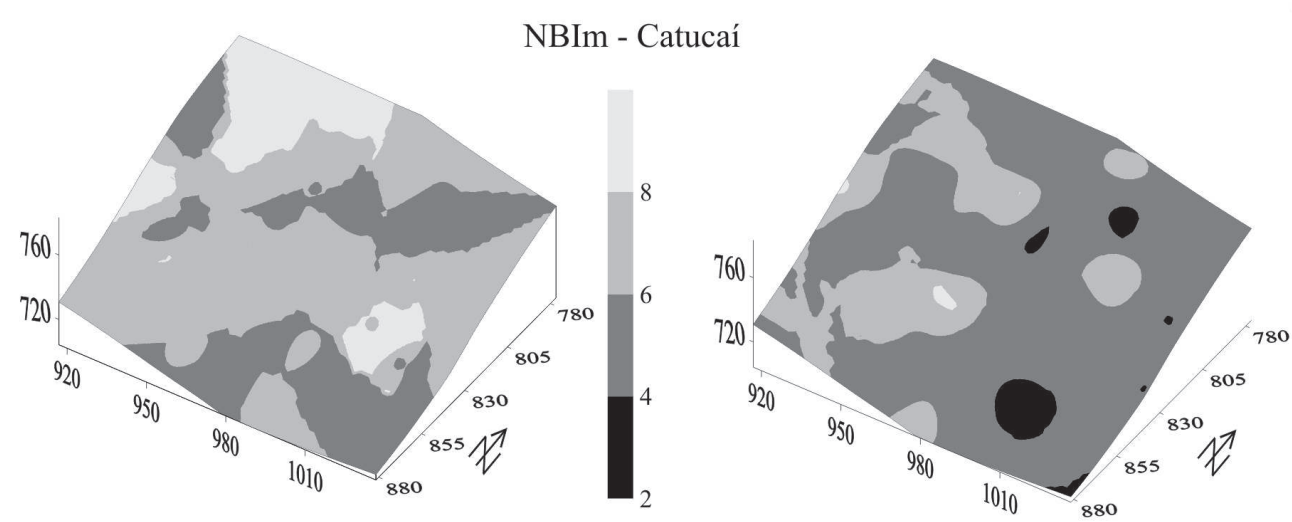

Catucaí
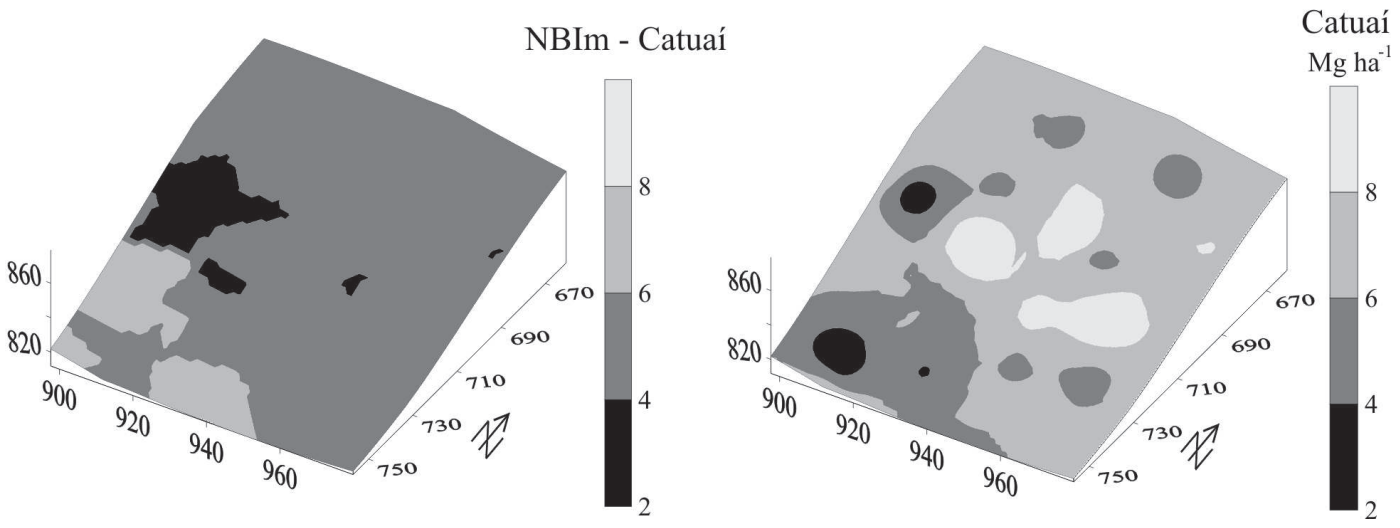

Figure 1 - Isoline maps of NBIm and yield in areas cultivated with coffee varieties Catucaí and Catuaí.
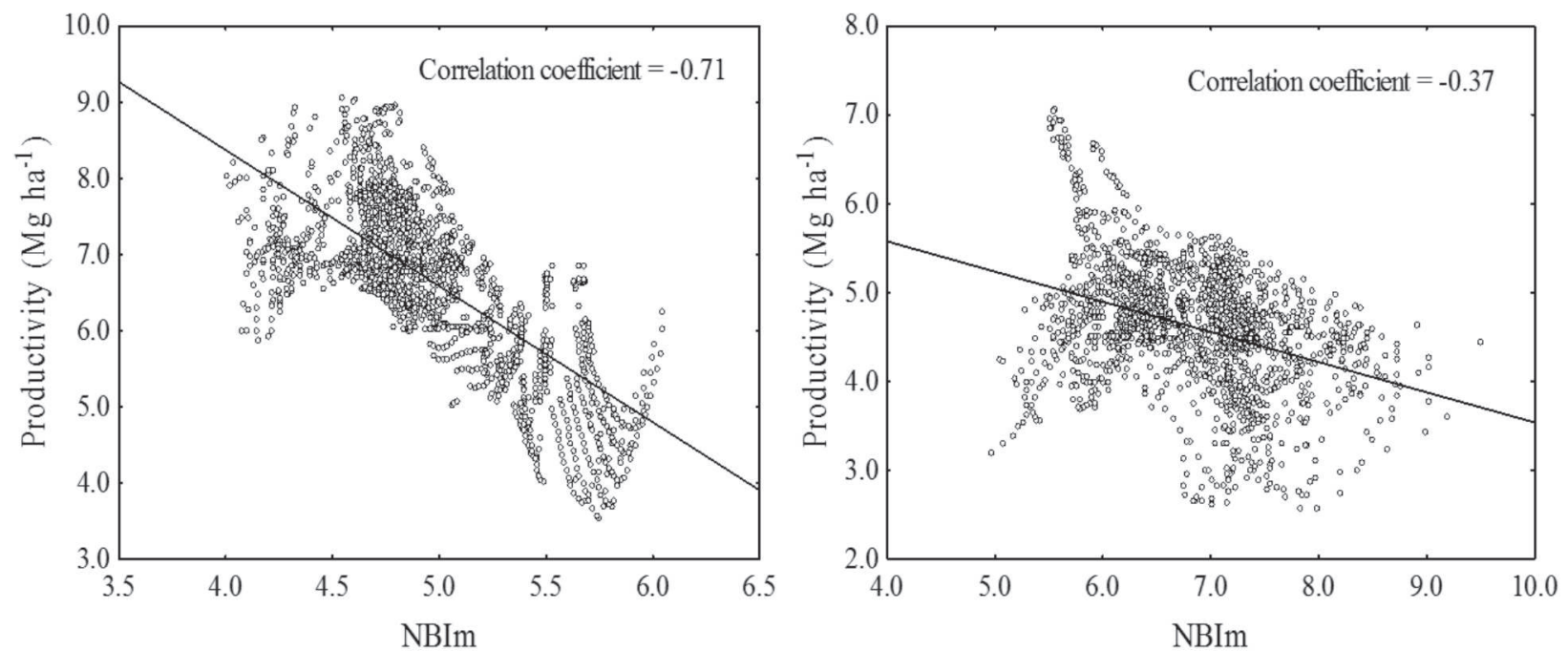

Figure 2 - Spatial correlation between yield and NBIm for coffee varieties Catucaí and Catuaí

Rev. Ceres, Viçosa, v. 58, n.2, p. 256-261, mar/abr, 2011 
As expected, the correlation coefficient between yield and NBIm was negative for both varieties, i.e., there is an increase in production when the balance of the crop is higher.

Although significant, variety Catucaí showed low spatial correlation between NBIm and yield (-0.37). This result can be explained by the higher variability observed in this variety, suggesting that greater efforts should be directed to overcome this variability, in order to better exploit their productive potential, which, according to Matiello \& Almeida (1997), is similar and in some cases higher than the best Catuaí lines.

\section{CONCLUSIONS}

Fe and $\mathrm{Mn}$ are in excess, limiting the yield of both varieties, mainly of variety Catucaí, which is more nutritionally imbalanced and, consequently, has lower yield.

The spatial correlation was higher when the spatial variability was lower because of the occurrence of specific management zones.

\section{REFERENCES}

Andrade WEB \& Ferreira JM (2004) Índices de deficiência e excesso de macro e micronutrientes em lavouras cafeeiras do Estado do Rio de Janeiro. In: Congresso Brasileiro de Pesquisas Cafeeiras, São Lourenço, MG. Anais, Fundação PROCAFE. p.75-76.

Barbosa DHSG, Vieira HD, Partelli FL \& Souza RMde (2006) Estabelecimento de normas DRIS e diagnóstico nutricional do cafeeiro arábica na região noroeste do Estado do Rio de Janeiro. Ciência Rural, 6:86-94.

Bataglia OC, Quaggio JA, Santos WR, Abreu MF (2004) Diagnose nutricional do cafeeiro pelo DRIS variando-se a constante de sensibilidade dos nutrientes de acordo com a intensidade e freqüência de resposta na produção. Bragantia, 2:253-263.

Beaufils ER (1973) Diagnosis and recommendation integrated system (DRIS). A general scheme of experimentation and calibration based on principles developed from research in plant nutrition. University of Natal, Pietermaritzburg, South Africa. Soil Science Bulletin, 1:132.

Carvalho VB (2005) Diagnóstico nutricional do cafeeiro arábica da região de Manhuaçu - MG. In: Simpósio de Pesquisa Dos Cafés Do Brasil, Londrina, PR. Anais, EMBRAPA, CD-ROM.

EMBRAPA - Empresa Brasileira de Pesquisa Agropecuária. Centro Nacional de Pesquisa de Solo (1997) Manual de métodos de análise de solo. $2^{\text {a }}$ ed. Rio de Janeiro, EMBRAPA. Serviço Nacional de Levantamento e Conservação de Solo. 212p.

EMBRAPA - Empresa Brasileira de Pesquisa Agropecuária (1999) Sistema brasileiro de classificação de solos. $1^{a}$ ed. Brasília, Centro Nacional de Pesquisa de Solos. 412p.

Guimarães EC (2000) Variabilidade espacial de atributos de uma latossolo vermelho escuro textura argilosa da região do cerrado, submetido ao plantio direto e ao plantio convencional. Tese de Doutorado, Faculdade de Engenharia Agrícola, Universidade Estadual de Campinas, Campinas, 85 p.

Jones WW (1981) Proposed modifications of the diagnosis and recommendation integrated system (DRIS) for interpreting plant analyses. Communications in Soil Science and Plant Analysis, 12:785-794.
Malavolta E (1986). Nutrição, adubação e calagem para o cafeeiro. In: Rena AB, Malavolta E, Rocha M, Yamada T (Eds.) Cultura do cafeeiro: fatores que afetam a produtividade. Piracicaba: Potafos, p 136-274.

Marschner H (1995) Mineral nutrition of higher plants. San Diego: Academic Press, 889 p.

Martinez HEP, Souza RB, Alvarez VH, Menezes JFS, Neves YP, Oliveira JA, Alvarenga AP, Guimarães PTG (2004) Nutrição mineral, fertilidade do solo e produtividade do cafeeiro nas regiões de Patrocínio, Manhuaçu, Viçosa, São Sebastião do Paraíso e Guaxupé. $2^{\mathrm{a}}$ ed. Belo Horizonte, Boletim Técnico $\mathrm{n}^{\circ} .72$, EPAMIG, 60 p.

Matiello JB \& Almeida SR (1997) Variedades de café - como escolher, como plantar. Rio de Janeiro, MAA/SDR/PROCAFÉ. $64 p$.

Molin JP \& Menegatti L (2005) Aplicação com taxa variável: tratamento localizado. Cultivar Máquinas, 3:22-26.

Reis JR RdosA \& Monnerat PH (2003) DRIS norms validation for sugarcane crop. Pesquisa Agropecuária Brasileira, 38:379-385.

Reis Júnior RdosA, Corrêa JB, Carvalho JGde, Guimarães PTG (2002) Estabelecimento de normas DRIS para o cafeeiro no sul de Minas Gerais: $1^{a}$ aproximação. Ciência e Agrotecnologia, 2:269-282.

Silva EB, Nogueira FD \& Guimarães PTG (2003) Uso do DRIS na avaliação do estado nutricional do cafeeiro em resposta à adubação potássica. Revista Brasileira de Ciência do Solo, 27:247255 .

Tomaz MA, Sakiyama NS, Martinez HEP, Cruz CD, Pereira AA, Freitas RSde (2005) Porta-enxertos afetando o desenvolvimento de plantas de Coffea arabica L.. Ciência Rural, 3:124-132.

Wadt PGS (1996) Os métodos da chance matemática e do sistema integrado de diagnose e recomendação (DRIS) na avaliação nutricional de plantios de eucalipto. Tese Doutorado, Universidade Federal de Viçosa, Viçosa, 123 p.

Zimback CRL (2001) Análise espacial de atributos químicos de solos para fins de mapeamento da fertilidade do solo. Tese Livre-Docência, Faculdade de Ciências Agronômicas, Universidade Estadual Paulista, Botucatu, 114 p. 